\title{
Foliar diseases of willows (Salix spp.) in selected locations of the Karkonosze Mts. (the Giant Mts)
}

\author{
Wojciech Pusz • Jacek Urbaniak
}

Accepted: 6 October 2016/Published online: 11 October 2016

(C) The Author(s) 2016. This article is published with open access at Springerlink.com

\begin{abstract}
The species of Salix herbacea L. and Salix lapponum L. are the rare relicts within the genus of Salix. With respect to their phylogeography, they are classified into the taxa of the Arctic-Alpine distribution. They can be found in the Arctic zone (Greenland, Scandinavia, Spitsbergen) as well as in such geographically separated areas as the mountains of lower latitudes like the Alps, the Sudetes or the Carpathians. Another species of willow occurring in the mountains of Europe, and more specifically on montane positions of the BalkanCarpathian distribution is $S$. silesiaca. The aim of the study was to determine the severity of the diseases of the willows growing in selected locations in the Karkonosze Mountains. The research was conducted in the years 2014 and 2015 in the Kociol Łomniczki [the Lomniczka Cirque] and the Wielki and Maty Śnieżny Kociot, [the Great and Small Snowy Cirques] at intervals of 4 weeks, from April to October. Field observations included the species of the genera Salix: S. herbacea, S. silesiaca and S. lapponum. Disease symptoms were identified with the percentage of infected plants at selected locations, as well as the percentage of infected leaves, recorded. In the course of the
\end{abstract}

\footnotetext{
W. Pusz $(\bowtie)$

Department of Plant Protection, Division of Plant Pathology and Mycology, The Wroclaw University of Environmental and Life Sciences, Grunwaldzki Sq. 24a, 50-363 Wroclaw, Poland e-mail: wojciech.pusz@up.wroc.pl

J. Urbaniak

Department of Botany and Ecology, The Wroclaw University of Environmental and Life Sciences, Grunwaldzki Sq. 24a, 50-363 Wroclaw, Poland
}

research, symptoms of rust caused by Melampsora epitea and $M$. alpina ( $S$. herbacea and $S$. silesiaca), black spot blight caused by Rhytisma salicinum (S. silesiaca) and leaf spot, probably caused by a complex of fungal taxa (S. herbacea), were detected on the leaves of Salix spp. growing in post glacial cirques. During the study period, there were no disease symptoms on S. lapponum. A total of 13 species of fungi were isolated from the infected leaves of $S$. herbacea. In the first year, the highest share in the fungal assembly was taken by Penicillium notatum, followed by Alternaria alternata and an unidentified species of the genus Ceuthospora. In the second year of the research, Ceuthospora spp. and A. alternata predominated in the species assembly of fungi in the infected leaves of the herb willow.

Keywords Willow.S. herbacea S. lapponum . Pathogenic fungi

\section{Introduction}

The Karkonosze Mountains (the Giant Mountains) are located in Central Europe, in the borderland between Poland and the Czech Republic. Compared to other European mountain ranges, these are characterised by a more varying geological formation, the varied lie of the land, severe alpine climate and patchy vegetation cover. In the Karkonosze Mountains, there are altitudinal zonations: the subalpine zone, 1250-1450 m above sea level, is covered with the Mountain Pine (Pinus mugo L.), an endemic and relict species (Przewoźnik 2008). 
The species of Salix herbacea L. and Salix lapponum L. are the rare relicts within the genus of Salix. With respect to their phylogeography, they are classified into the taxa of the Arctic-Alpine distribution. They occur in the Arctic zone (Greenland, Scandinavia, Spitsbergen), and in the mountains of much lower latitudes (the Alps, the Sudetes and the Carpathians) (Kornaś and Medwecka-Kornaś 2002). The dwarf willow ( $S$. herbacea) is a tiny, inconspicuous shrub. The sparsely distributed locations of this species have been recorded in Poland at the Alpine and sub-nival levels (Kwiatkowski 2008; Kwiatkowski and Żołnierz 2013). The dwarf willow has also been found in three locations in the Giant Mountains, where it grows in rock crevices and on wind-swept snow outcrops, enduring, as the majority of the Arctic-Alpine species, the extremely severe climatic conditions. Likewise, the downy willow (S. lapponum), although apparently larger in size and occasionally forming fairly extensive thickets along watercourses, is a species rarely identified in Poland (Kornaś and Medwecka-Kornaś 2002). Another willow species that occurs in the mountains of Europe, particularly in the mountainous areas of the Balkan-Carpathian distribution, is Salix silesiaca Willd. The occurrence of this species, much like the occurrence of the similarly shaped S. lapponum, is associated with the presence of surface watercourses and of extensive soil moisture content (Veselá 1995). S. silesiaca can be found in Poland in the Izerskie Mountains, as well as in the Giant Mountains.

Several species of plant-pathogenic fungi may occur on Salix plants in Poland. In particular, in cases where the willow is cultivated for energy biomass, these pathogens may cause considerable damage in terms of economy. The most dangerous of them are undoubtedly the species of Melampsora genus, causing rust symptoms (Remlein-Starosta 2007). M. epitea and M. caprearum are most often found on the leaves of different willow species (Oein et al. 1999; Błażej 2007; Pei et al. 2008). In willow cultures, the rust may cause losses as high as $40 \%$ (Remlein-Starosta 2007). Moreover, the fungi of the genus Melampsora are the ones most often identified on wild willows (Chlebicki 2002; Smith et al. 2004). Another dangerous disease that occurs on Salix plants is the willow scab, caused by Venturia saliciperda. Apart from the willow scab, the twigs of willows also show the presence of Anthracnose caused by Glomerella cingulata, and by the fungi of the genus Colletotrichum (Remlein-Starosta 2007). On the other hand, on the leaves of the willow, next to rusts and scab, there may appear "spot" symptoms, brought on by several fungi species including Rhytisma salicinum or Drepanopeziza spaerioides. In some years, the latter diseases may occur with great intensity, particularly on older trees (Dłużniewska 2007, 2011).

The aim of the study was to determine the intensity of foliar disease of willows, within the selected locations in the Karkonosze Mountains.

\section{Material and methods}

The research was conducted in the locations of Kociot Łomniczki [Łomniczka Cirque] and in Mały Śnieżny Kociot and Wielki Śnieżny Kociot, [the Great and Small Snowy Cirques] in 2014-2015. The observations were carried out at four-week intervals from April to October and included 30 to 35 plants of each selected Salix location: S. herbacea, S. lapponum and $S$. silesiaca. The symptoms of the infections were described and, in selected locations, the percentage of the affected plants as well as of the infected leaves was determined. If fruiting bodies were found, the fungi were identified taxonomically according to their morphology. The condition of $S$. herbacea plants grown in conservation culture within 'Żywy Bank Genów Jagniątków' (Live Gene Bank of the Karkonoski National Park in Jagniątków, further abbreviated as LGB), and in the garden of KPN Information Centre in Karpacz (further abbreviated as IC) was assessed for ' reference,. The percentage of infection was analysed to establish the variance (ANOVA). Prior to the ANOVA analysis, the percentage data were transformed using the Bliss (1938) formula based on the R programming language.

Afterwards, the leaves of $S$. herbacea on which the infection symptoms were found to cover $>60 \%$ of the leaf blade area, were selected for mycological analysis. The leaf samples were taken in July and in August. They were transported, in paper envelopes, to the laboratory, where they were rinsed with sterile water and immersed for several seconds in a disinfectant, $1 \%$ solution of sodium hypochlorite. Subsequently, sections $0.3-\mathrm{cm}$ in diameter were sampled from individual leaves using cork borer. These were placed on standard PDA medium (Potato Dextrose Agar, Difco) in Petri dishes. The growing colonies of the fungi were consequently re-planted onto PDA slants in order to be cultured further and to be 
determined taxonomically. The pathogens were identified on the strength of their morphological traits, as described in the monographs (Pitt and Hocking 2009) and (Watanabe 2011), and adopting molecular techniques.

DNA isolation from the fungi cultured in the agar slants was performed implementing CTAB method with ethanol precipitation (Doyle and Doyle 1987). The quality and effectiveness of the isolation was checked on $1 \%$ agarose gel. In order to identify the fungal species, the amplification and sequencing of the non-coding regions of ITS was applied, using ITS1 and ITS4 specific starters (Gardes and Bruns 1993; White et al. 1990, respectively). The PCR reactions were initiated using Taq polymerase (Thermo Scientific, Waltham) in thermocycler Veriti (Applied Biosystems, Waltham). PCR reaction products were separated in $1.5 \%$ agarose gel and purified by ethanol precipitation or by the application of ExoBap kit (EurX, Gdańsk). Sequencing reactions and the separation on sequencer were produced by the sequencing and synthesis service of Genomed (Warsaw). The analysis of the obtained readings and the assembly of the sequences were performed with FinchTV (Geospiza 2004) and DNA Baser (2014) software, whereas the homology of thus obtained sequences with the sequences contained in Genebank database was determined using BLAST (Basic Local Alignment Search Tool) (2015).

\section{Results}

Field study

In the course of the study, rust and black spot blight symptoms were detected on the leaves of Salix silesiaca and rust and leaf spot on $S$. herbacea growing in the post-glacial cirques. Rust symptoms on $S$. herbacea and on $S$. silesiaca turned out to be caused by Melampsora epitea and M. alpina, whereas black spot blight on S. silesiaca was attributed to Rhytisma salicinum, and on $S$. herbacea to a complex of pathogenic fungi. No disease symptoms were identified on S. lapponum while conducting the research.

In the first year of the study, the first symptoms in the location of LGB in Jagniatków were already noticed in May, though in the natural locations they were only seen in August. Dark, irregular patches were gradually showing on the leaves and consequently, the infected leaves were turning yellow and dying away. During the same month in which these symptoms were recognised, tiny yellowish spots were appearing on the adaxial side of the leaves. On the abaxial side of the leaf blades, opposite the spots on the upper surface, yellowish-orange aggregations of spores were observed. In the following months, the infected leaves were shed, leaving the twigs of the host plant defoliated. In the second year of the study, i.e. 2015, an observation was made that no leaves were produced on the previously defoliated twigs. Instead, new leaves formed exclusively on annual twigs. In that year, the first symptoms in LGB location were detected by the end of June, whereas in the natural locations, in July. It is noteworthy that the plants of $S$. herbacea in LGB showed the symptoms later and those at Maty Śnieżny Kociot, earlier, compared to the year 2014. Conversely, no rust symptoms were observed in 2015 in LGB or in the natural locations; the symptoms caused by Melampsora spp. fungi were detected in that year only on the plants of $S$. herbacea grown in conservative cultures of the IC in Karpacz.

$S$. herbacea was infected to the greatest extent in the LGB locations at Jagniątków. The symptoms in May were detected on $5 \%$ of individuals, but already in June $60 \%$ of the plants were showing signs of the infection. Premature leaf shedding was observed there in July, accompanied by nearly $100 \%$ infection by both rust and leaf spot. In the second year of the study, the symptoms of leaf spot in LGB were only recognised on single, individual plants. In one of the natural locations, over the Mały Śnieżny Kocioł, close to a relay station, the symptoms in 2014 were recorded on $70 \%$ of the observed plants, and they covered up to $100 \%$ of the leaf blade area. In September that year mass shedding of the infected leaves was noticed, with black telia with teliospores showing on them. In the second year, leaf spot symptoms were evident on $100 \%$ of the observed plants. The spots on the infected leaves covered $20 \%$ of the leaf blade area in July, only to advance to $90 \%$ before August.

The symptoms of rust on $S$. silesiaca were detected in all the locations under study. The plants growing in Mały Śnieżny Kocioł were infected to the highest degree. In July, the yellowish aggregations of urediniospores were visible on the abaxial side of leaves. In August, dark, tarred and slightly convex patches were observed on the adaxial side of leaf blades, which would crumble out of the leaves in the following months. In the first year of the study, such symptoms 
were observed on $30 \%$ of individual plants, similarly to the signs of black spot blight caused by $R$. salicinum. In the second year, the first symptoms of both rust and black spot blight were noticed only in August; these symptoms were identified on single individuals only (Table 1).

\section{Laboratory study}

A total of 13 species of fungi were isolated from the leaves of $S$. herbacea showing the symptoms (Table 2). Among them, Penicillium notatum occurred in the highest proportion (19\%), relative to the other isolated taxa in the first year of the study, followed by Alternaria alternata (17\%) and by a species of the Ceuthospora genus $(15 \%)$. In the second year, Ceuthospora spp. $(18 \%)$ and A. alternata $(18 \%)$ predominated in the fungal assemblage of the infected leaves of $S$. herbacea, with P. notatum keeping up closely (16\%). Interestingly, an unidentified species of the Colletotrichum genus made up a considerable proportion of all the isolated taxa in both study years: $14 \%$ in 2014 and $12 \%$ in 2015.

\section{Discussion}

Until now, the majority of publications on the diseases of the Salix genus focused on the pathogenic fungi infecting energy-biomass willow (Błażej 2007; Remlein-Starosta 2007; Dłużniewska 2011). Few researchers mention pathogens infecting the tissue of Salix spp. that grow in natural locations (Smith et al. 2004; Adamska 2005; Mühlmann and Peintner 2008). Individuals of S. herbacea and S. silesiaca growing in the Karkonosze region are predominantly infected by the fungi of Melampsora genus: $M$. epitea and M. alpina. The works by other authors confirm that the fungi of Melampsora spp. most often occur on cultivated forms as well as on the plants growing in natural conditions (Adamska 2005; Mühlmann and Peintner 2008). Moreover, Adamska (2005) has observed symptoms of powdery mildew caused by Uncinula adunca, on the willows in Słowiński National Park, and spot symptoms with such pathogen species as Phyllosticta salicicola and Septoria salicicola. The author does not mention in her work the fungus of Rhytisma salicinum, although this species occurs fairly commonly on Salix spp. and was recorded for the first time in the Karkonosze Mountains at the end of the 19th. century, and described by Schroeter (1908). Incidentally, Schroeter also mentions rust species infecting S. lapponum - M. epitea and Mollisia cinerea.

The research by Chlebicki (1999), conducted in late 90s of the nineteenth century, confirmed the occurrence of only one of those species: $M$. cinerea. Curiously, the same author confirmed the presence of other five species of fungi on S. lapponum,. These were Coryne dubia, Cryptodiaporthe salicella, Melanomma pulvis-pyrius, Nectria coryli and Taeniolella scripta. Chlebicki (1999) then proved that the species composition of the fungi infecting different plant parts of S. lapponum in the

Table 1 The occurrence of diseases on the leaves of Salix spp. in the Karkonosze Mts. (2014-2015)

\begin{tabular}{|c|c|c|c|c|c|c|c|c|c|}
\hline \multirow[t]{3}{*}{ Localisation } & \multicolumn{6}{|c|}{ Percent of infected plants } & \multicolumn{3}{|c|}{ Infections index } \\
\hline & \multicolumn{2}{|l|}{ Rust } & \multicolumn{2}{|c|}{ Black spot blight } & \multicolumn{2}{|c|}{ Leaf's spot } & \multirow[t]{2}{*}{2014} & \multirow[t]{2}{*}{2015} & \multirow[t]{2}{*}{ Average } \\
\hline & 2014 & 2015 & 2014 & 2015 & 2014 & 2015 & & & \\
\hline \multicolumn{10}{|l|}{ Salix herbacea } \\
\hline Nad Małym Śnieżnym Kottem & 70 & - & $\mathrm{x}$ & $\mathrm{x}$ & 70 & 90 & $70 \mathrm{a}$ & $90 \mathrm{~b}$ & $80 \mathrm{a}$ \\
\hline Live Gene Bank & 100 & - & $\mathrm{x}$ & $\mathrm{x}$ & 100 & $<10$ & $100 \mathrm{c}$ & $10 \mathrm{~d}$ & $55 \mathrm{e}$ \\
\hline KPN Information Centre & - & 100 & $\mathrm{x}$ & $\mathrm{x}$ & - & $<10$ & $100 \mathrm{e}$ & $10 \mathrm{f}$ & $55 \mathrm{e}$ \\
\hline \multicolumn{10}{|l|}{ Salix silesiaca } \\
\hline Kocioł Łomniczki & 30 & $<10$ & 30 & $<10$ & $\mathrm{x}$ & $\mathrm{x}$ & $30 \mathrm{~g}$ & $10 \mathrm{~h}$ & $20 \mathrm{i}$ \\
\hline Wielki Śnieżny Kocioł & 30 & $<10$ & 40 & $<10$ & $\mathrm{x}$ & $\mathrm{x}$ & $35 \mathrm{~g}$ & $10 \mathrm{~h}$ & $22 \mathrm{i}$ \\
\hline Maty Śnieżny Kociol & 30 & $<10$ & 30 & $<10$ & $\mathrm{x}$ & $\mathrm{x}$ & $30 \mathrm{~g}$ & $10 \mathrm{~h}$ & $20 \mathrm{i}$ \\
\hline
\end{tabular}

Means followed by the same letter do not differ significantly. Fisher's least significant difference (LSD) test, $\alpha \leq 0.05$ 


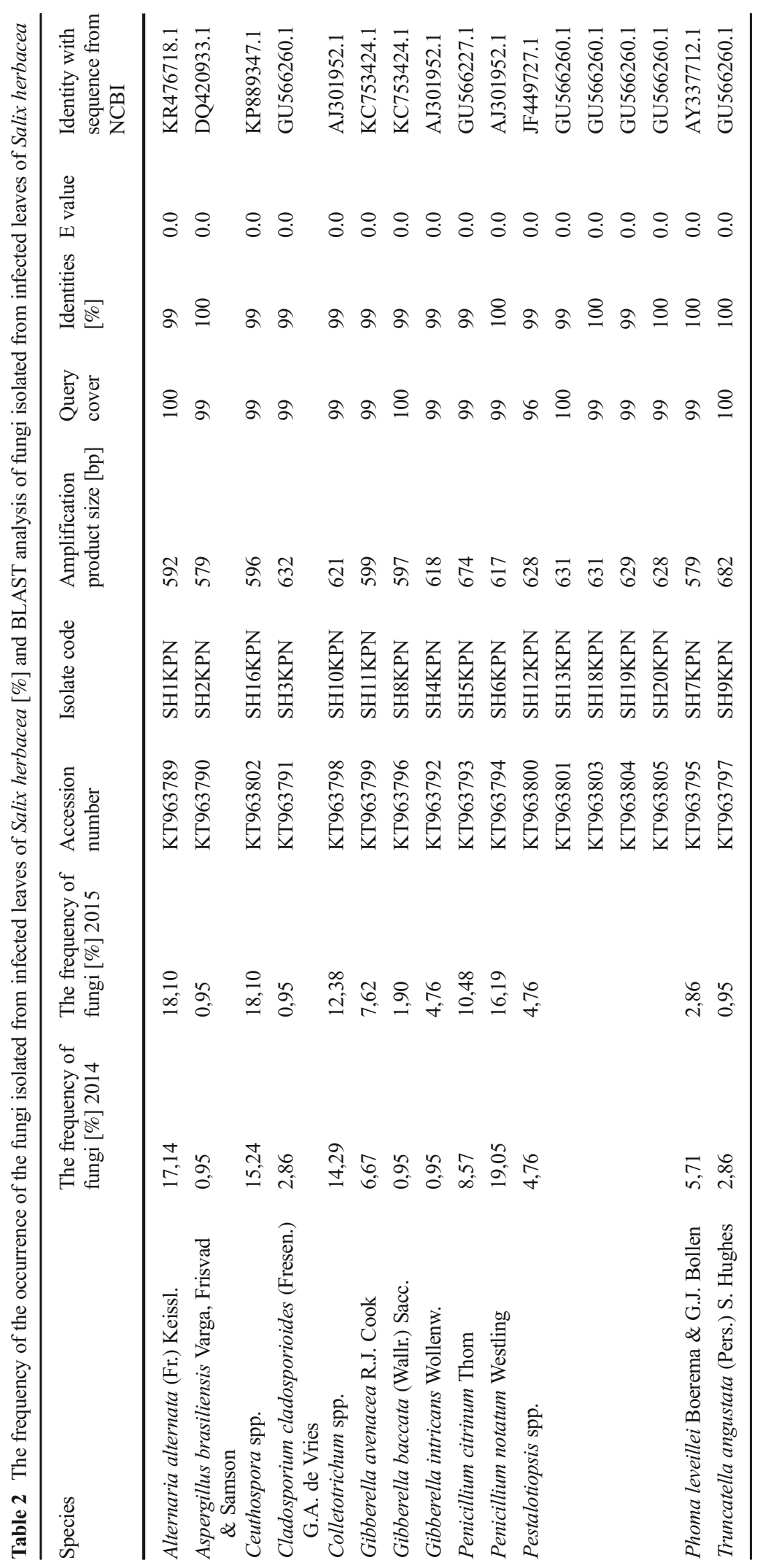


Karkonosze Mountains was clearly different from the one identified by Mathiassen (1993) in Scandinavia. The observations carried out in 2014-2015 by the authors of the present article did not record the occurrence of any of the fungi species listed before. It is difficult to make a judgement of what factors contributed to the present situation because Chlebicki (1999) had noted these species on twigs, not on leaves. However, it seems clear that conducting plant-pathological surveys within the regions of considerable natural value is an important element of environmental monitoring. Chlebicki (1999) argued that it was environmental pollution, which resulted in the absence of $R$. salicinum in the region during his research. Nor did the authors of this article find $R$. acerinum on $S$. lapponum. They found this species on S. silesiaca, which, however, was not investigated by Chlebicki 1999, 2002). Indeed, Rhytisma spp. are particularly vulnerable to $\mathrm{SO}_{2}$ in the atmosphere, and the issue of pollution was practically non-existent in the Karkonosze Mountains by the end of nineteenth century, the time when the species was identified there by Schroeter.

We isolated, from the infected leaves, pathogenic as well as saprophytic species of fungi. The species composition under study resembled the one reported by Corredor et al. (2012), who had been isolating not only fungi of the genera Alternaria, Fusarium and Aspergillus, but also Truncatella angustata from the roots; nevertheless, he had not reported the presence of the genus Penicillium or C. cladosporioides, which colonise dead organic matter and were otherwise isolated from the dead leaves of $S$. herbacea (Longa et al. 2005). Little research has investigated the problem of pathogenic fungi on $S$. herbacea. Beerling (1998) postulated that $S$. herbacea is resistant to infections by potential pathogens. He included rust fungi of the Melampsora genus: M. arctica and M. larici-epitea in the most important pathogens of Salix (Beerling 1998). It is vital that further research is undertaken in order to determine the interactions between plant-pathogenic fungi, host and theirs adaptation to extremely conditions like high mountains.

\section{Conclusions}

1. Salix herbacea in the Karkonosze Mountains is infected by pathogenic fungi to a considerable degree. Individuals of $S$. silesiaca are infected to a lesser extent.
2. The most frequent disease of the willow leaves is rust caused by the species of the genus Melampsora.

Acknowledgments The work was funded by the Forest Fund of PGL "Lasy Państwowe (National Forests)".

Open Access This article is distributed under the terms of the Creative Commons Attribution 4.0 International License (http:// creativecommons.org/licenses/by/4.0/), which permits unrestricted use, distribution, and reproduction in any medium, provided you give appropriate credit to the original author(s) and the source, provide a link to the Creative Commons license, and indicate if changes were made.

\section{References}

Adamska, I. (2005). Grzyby pasożytnicze roślin z rodzaju Betula L. i Salix L. [parasitic fungi of the plants of Betula L. and Salix L. genera]. Acta Agrobotanica, 58(2), 417-428.

Beerling, D. J. (1998). Biological flora of the British isles: Salix herbacea L. Journal of Ecology, 86, 872-895.

BLAST (2015) NCBI (National Centre for Biotechnology Information). (http://blast.ncbi.nlm.nih.gov/Blast.cgi).

Błażej, J. (2007). Nieinfekcyjne i infekcyjne czynniki chorobotwórcze krzaczastej formy wierzby (Salix viminalis L.) uprawianej na plantacjach towarowych w województwie podkarpackim. [non-infective and infective disease factors of shrub willow (Salix viminalis L.) grown as commercial crops in the Sub-Carpathian Province]. Progress in Plant Protection, 47(4), 321-329.

Bliss, C. I. (1938). The transformation of percentages for use in the analysis of variance. The Ohio Journal of Science, 38, 9-12.

Chlebicki, A. (1999). Grzyby zebrane na gnidoszu sudeckim (Pedicularis sudetica ssp. sudetica), skalnicy śnieżnej (Saxifraga nivalis) i wierzbie lapońskiej (Salix lapponum) w Karkonoszach [fungi collected on Sudetic Lousewort (Pedicularis sudetica ssp. sudetica), snow saxifrage (Saxifraga nivalis) and downy willow (Salix lapponum) in the Karkonosze Mountains]. Przyroda Sudetów Zachodnich, 2, 15-20.

Chlebicki, A. (2002). Biogeographic relationships between fungi and selected glacial relict plants. Monographiae Botaniceae, 90, 1-230.

Corredor, A. H., Van Rees, K., \& Vujanovic, V. (2012). Changes in root-associated fungal assemblages within newly established clonal biomass plantations of Salix spp. Forest Ecology and Management, 282, 105-114.

Dłużniewska, J. (2007). Podatność wybranych klonów wierzby energetycznej (Salix sp) na choroby grzybowe [susceptibility of selected clones of energetic willow (Salix sp) to fungal diseases]. Progress in Plant Protection, 47(4), 334-338.

Dłużniewska, J. (2011). Występowanie chorób powodowanych przez grzyby na wierzbie (Salix sp.) w zależności od wieku roślin [Occurrence of fungal diseases in willow (Salix sp.) depending on the plant's age]. Progress in Plant Protection, 51(3), 1146-1149. 
DNA Baser Sequence Assembler (2014) Heracle BioSoft SRL version 3.5.3.216.

Doyle, J. J., \& Doyle, J. L. (1987). A rapid DNA isolation procedure for small quantities of fresh leaf tissue. Phytochemical Bulletin, 19, 11-15.

Finch, T. V. (2004). Geospiza. Perkin: Elmer Version 1.4.

Gardes, M., \& Bruns, T. D. (1993). ITS primers with enhanced specificity for basidiomycetes - application to the identification of mycorrhizae and rusts. Molecular Ecology, 2, 113-118.

Kornaś J, Medwecka-Kornaś A (2002) Geografia roślin [Geography of Plants]. PWN, Warszawa. ss. 634.

Kwiatkowski, P. (2008). Rośliny naczyniowe Karkonoszy i Pogórza Karkonoskiego [Vascular plants of the Karkonosze Mountains and the Karkonosze Foothills]. Przyroda Sudetów, 11, 3-42.

Kwiatkowski P, Żołnierz L (2013) Rośliny kwiatowe. W: Knapik R., Raj A. (red), Przyroda Karkonoskiego Parku Narodowego. [Angiosperms. In: Knapik R., Raj A. (ed), Natural surroundings of Karkonoski National Park], Jelenia Góra: 217-240.

Longa, C. M. O., Palma, L., \& Tosi, S. (2005). Conidial fungi from Salix herbacea leaf litter and their growth temperature preferences. Boletín Micológico, 20, 91-95.

Mathiassen, G. (1993). Corticolous and lignicolous Pyrenomycetes s. lat. (Ascomycetes) on Salix along a midScandinavian transect. Sommerfeltia, 20, 1-170.

Oein, M., Hunter, T., \& Ruiz, C. (1999). Occurrence of Melampsora rust in biomass willow plantations for renewable energy in the United Kingdom. Biomass and Bioenergy, 17(2), 153-163.

Pei, M., Lindegaard, K., Ruiz, C., \& Bayon, C. (2008). Rust resistance of some varieties and recently bred genotypes of biomass willows. Biomass and Bioenergy, 32, 453-459.

Pitt, J. I., \& Hocking, A. D. (2009). Fungi and food spoilage. New York: Springer, USA.

Przewoźnik L (2008) Rośliny Karkonoskiego Parku Narodowego. [Plants of Karkonosze National Park] Press, Jelenia Góra. (in Polish)

Remlein-Starosta, D. (2007). Choroby roślin energetycznych. [diseases of energy biomass plants]. Progress in Plant Protection, 47(4), 351-357.

Schroeter J (1908) Pilze. In: Cohn's Krypt. - Fl. Schlesiens 3 (2), Die Pilze Schlesiens II. Breslau: ss. 597.

Smith, J., Blanchete, R., \& Newcombe, G. (2004). Molecular and morphological characterization of the willow rust fungus, Melampsora epitea, from arctic and temperate hosts in North America. Mycologia, 96(6), 1330-1338.

Veselá, M. (1995). Salix silesiaca communities in the Fatra Mts. (Central Slovakia). Folia Geobotanica, 30(1), 33-52.

Watanabe, T. (2011). Pictorial atlas of soil and seed fungi: morphologies of cultured fungi and key to species. USA: CRC press.

White TJ, Bruns TD, Lee S, Taylor J (1990) Amplification and direct sequencing of fungal ribosomal RNA genes for phylogenetics. Pp. 315-322 in PCR Protocols: A Guide to Methods and Applications (Innis, N., D. Gelfand, J. Sninsky \& T. White, Eds.), Academic Press. 